\title{
Turnover of [14C] sucrose HDL and uptake by organs in the normal or genetically hypercholesterolemic (RICO) rat using a constant infusion method
}

\author{
C Lutton *, K Ouguerram, M Sauvage, T Magot \\ Laboratoire de Physiologie de la Nutrition, URA D.0646 CNRS - Bâtiment 447, \\ Université de Paris-Sud, 91405 Orsay Cedex, France
}

(Received 13 January 1989; accepted 7 November 1989)

\begin{abstract}
Summary - The turnover and tissular uptake of HDL (d 1.095-1.21) have been compared in normocholesterolemic or genetically hypercholesterolemic rats by a constant infusion method of $\left[{ }^{14} \mathrm{C}\right]$ sucrose labelled HDL for $8 \mathrm{~h}$. The HDL clearance rate was not significantly smaller in the RICO than in the normocholesterolemic animal (320 $\pm 22 \mu \mathrm{l}^{\mathrm{h}} \mathrm{-1}$ versus $366 \pm 24 \mu \mathrm{l} \cdot \mathrm{h}^{-1}$ per $100 \mathrm{~g}$ of rat). It was the same case for the fractional catabolic rate, respectively equal to 7.8 and $9.4 \pm 0.6 \% \cdot \mathrm{h}-1$. For both strains, liver and skeletal muscle were the main catabolic sites for HDL. The HDL uptake rates in intestine or kidney were 3-4-fold smaller than those in the liver. In the RICO rat, intestine, testis and adrenals showed a lesser HDL uptake capacity (expressed per $g$ of organ) than the normocholesterolemic rat.
\end{abstract}

$\left[{ }^{14} \mathrm{C}\right]$ sucrose $\mathrm{HDL} /$ clearance rate / fractional clearance rate

\begin{abstract}
Résumé - Renouvellement plasmatique et captage tissulaire des HDL marquées au ${ }^{14} \mathrm{C}$ saccharose chez le rat normocholestérolémique ou génétiquement hypercholestérolémique (RICO) par une méthode d'infusion continue. Par une méthode d'infusion continue qui permet de maintenir pendant $8 \mathrm{~h}$ un équilibre isotopique dans le plasma de HDL marqués sur leurs apolipoprotéines par du [ $\left.{ }^{14} \mathrm{C}\right] \mathrm{saccharose}$, nous avons comparé le renouvellement plasmatique et le captage tissulaire des HDL (d 1,095-1,21) chez le rat normocholestérolémique et chez le rat génétiquement hypercholestérolémique (RICO). La vitesse de clairance totale des HDL n'est pas significativement plus basse chez le RICO que chez le normocholestérolémique (320 $\pm 22 \mu{ }^{\circ} h^{-1}$ contre $366 \pm 24$ $\mu / h^{-1}$ par $100 \mathrm{~g}$ de rat). II en est de même du taux de catabolisme, respectivement égal à 7,8 et 9,4 $\pm 0,6 \% \bullet h-1$. Chez les 2 souches de rats, le foie et le muscle squelettique représentent les principaux sites du catabolisme des HDL. La vitesse de captage des HDL par l'intestin grêle ou les reins est 34 fois plus faible que celle du foie. Chez le rat RICO, l'intestin grêle, les testicules et les surrénales présentent une moindre capacité de captage des HDL (exprimée par g d'organe) que le normocholestérolémique.
\end{abstract}

HDL [14C]saccharose / vitesse de clairance / taux de catabolisme

* Correspondence and reprints 


\section{INTRODUCTION}

In the rat, most plasma cholesterol is carried by high density lipoproteins. In the genetically hypercholesterolemic rat (RICO), high plasma cholesterol concentration results from an increase in the cholesterol content of the $d>1.006$ lipoproteins (Cardona-Sanclemente et al, 1988). Several approaches have been used in an attempt to determine the turnover and the quantitative importance of various tissues in the degradation of lipoproteins. The content of 125 | has been measured in various organs several $h$ after the intravenous administration of 125/-lipoproteins, but a rapid release of free 1251 can occur after tissue uptake of 125 l lipoproteins. The apolipoproteins have also been covalently linked to [14C] sucrose or to 125 -cellobiose which are not degraded by lysosomal enzymes and accumulate in the cell (Pittman et al, 1983). A simple constant infusion method has been described to measure plasma clearance rates of labeled lipoproteins and identify their catabolic tissue sites (Koelz et al, 1982). In this method, an initial bolus of $\left[{ }^{14} \mathrm{C}\right]$ sucrose-lipoprotein, administered intravenously, was followed by a subsequently adjusted hourly constant infusion rate of $\left[{ }^{14} \mathrm{C}\right]$ sucrose-lipoprotein necessary to achieve a constant level of radiolabeled lipoprotein in the plasma. We now report the results obtained with this last technique in the genetically hypercholesterolemic rat (RICO) and in the normocholesterolemic heterozygote (SW).

\section{MATERIALS AND METHODS}

\section{Animals and diet}

Male RICO and normocholesterolemic SW rats weighing 140-150 g came from the Ciba-Geigy breeding unit (Basel, Switzerland). As soon as they arrived the animals were kept at a constant temperature of $24 \pm 2{ }^{\circ} \mathrm{C}$ with an 8 am-8 pm photoperiod. They ingested the laboratory semisynthetic base diet containing $53 \%$ sucrose, $23 \%$ caseine, $9.2 \%$ lard, $5 \%$ mineral mix, $4 \%$ skim milk, 2.5 yeast, $2.5 \%$ vitamins, $0.8 \%$ walnut oil, $0.2 \%$ cystine (Cardona-Sanclemente et al, 1987) until they were 4 months old. The mean fatty acid (mol percentage) composition of the lard was: myristic < 5, palmitic 22-28, stearic 8-11, oleic 43-53, linoleic 12-13 and unsaturated $\mathrm{C}_{20-22}$ fatty acids $\leq 1$; that of walnut oil was: palmitic 4.6 , stearic 0.9 , oleic 18 , linoleic 73, linolenic 3.

\section{Isolation and labelling of Ilpoproteins}

High-density lipoproteins (HDL) in the density range of $1.095-1.21 \mathrm{~g} / \mathrm{ml}$ were isolated by preparative ultracentrifugation (Sérougne et al, 1984) from the plasma of male adult SW or RICO rats. They were then dialyzed against $20 \mathrm{mM}$ sodium phosphate buffer/1 $\mathrm{mM}$ EDTAV0.15 M NaCl (buffer $\mathrm{A}, \mathrm{pH} 7.2) .62 \mu \mathrm{Ci}$ of $\mathrm{U}\left[{ }^{14} \mathrm{C}\right]$ sucrose $(540$ $\mu \mathrm{Ci} / \mu \mathrm{mol}, 1 \mathrm{Ci}=3.7 .1010 \mathrm{~Bq}$ ) (CEA) and 112.5 $\mathrm{nmol}$ of sucrose were activated by reaction with 2 molar equivalents of cyanuric chloride (1, 3, 5trichloro 2, 4, 6 triazine, Aldrich) in aqueous acetone containing 3 equivalents of $\mathrm{NaOH}$, as described by Pittman et al (1979) with slight modifications. After $15 \mathrm{~s}$, the reaction was quenched by adding 4 equivalents of acetic acid. The resulting activated $\left[{ }^{14} \mathrm{C}\right]$ sucrose dichlorotriazine adduct was then added to 5-6 mg of HDL protein in buffer $\mathrm{A}, \mathrm{pH}$ 7.2. After $3 \mathrm{~h}$ at room temperature, $\left[{ }^{14 C}\right]$ sucrose $\mathrm{HDL}$ were separated from the low molecular weight products by gel filtration (Sephadex $G_{25}$ ) and dialysis in buffer $A$ $\mathrm{pH} 6.8$ then buffer $\mathrm{A}, \mathrm{pH}$ 7.2. The final preparation contained $1.5 \mu \mathrm{Ci} / \mathrm{mg}$ protein.

\section{Infusion method}

RICO and SW rats were fitted with a jugular vein catheter the day before the experiment. Each animal received an initial bolus $(500000-1000000 \mathrm{dpm}$ ) intravenously of lipoprotein in an amount equal to approximately 10 times the subsequent hourly infusion rate which was $1 \mathrm{ml} / \mathrm{h}$ with a solution containing $77.1 \mathrm{mM}$ 
$\mathrm{NaCl}, 20.6 \mathrm{mM} \mathrm{KCl}, 10.3 \mathrm{mM} \mathrm{KH}_{2} \mathrm{PO}_{4}, 550 \mathrm{mM}$ glucose and [ $\left.{ }^{14} \mathrm{C}\right]$ sucrose $\mathrm{HDL}(0.5-2 \mathrm{mg} / \mathrm{ml})$, to give approximately $50000-100000 \mathrm{dpm}$ of radioactivity per $\mathrm{ml}$. The infusion was continued at a constant rate for 8-10 h or adjusted in order to ensure isotope equilibrium. Blood samples $(\leq 200 \mu$ l) were regularly taken on the tail to check plasma radioactivity. The ratio of hourly infusion rate to initial bolus gave the fractional catabolic rate (FCR, \% $\mathrm{h}^{-1}$ ) of the labeled HDL (table I). Dividing the clearance rate by the theoretical plasma volume also allowed a close estimation of FCR. The animals were anesthetized by pentobarbital and blood was aspirated from the abdominal aorta. The circulatory system was extensively washed. Triplicate aliquots of plasma and triplicate samples of liver, kidney, adrenals, jejunum, spleen, testis, colon, caecum and skeletal muscle were then assayed for radioactivity. Preliminary assays showed that aliquots of the tissue and plasma samples subjected to lipid extraction gave results similar to those of nondelipidated samples. Consequently, the amount of ${ }^{14} \mathrm{C}$ in the tissue samples $(50-150 \mathrm{mg}$ ) was determined after digestion in $1 \mathrm{ml}$ of soluene 350 , acidification with acetic acid and counting in a Kontron scintillation spectrometer. The HDL clearance rate from the plasma was calculated as the ratio of dpm infused into the animal per $\mathrm{h}$ / lipoprotein-bound dpm per $\mu$ l plasma. This calculation gave the microliters of plasma cleared of $\mathrm{HDL}$ per $\mathrm{h}$ per animal or per $100 \mathrm{~g}$ of rat.

\section{RESULTS AND DISCUSSION}

Plasma cholesterol was $0.83 \pm 0.04$ and $1.73 \pm 0.15 \mathrm{mg} / \mathrm{ml}$ respectively in SW and RICO rats, in agreement with a previous study (Cardona-Sanclemente et al, 1987). Similar HDL clearance rates were obtained for both groups of animals (table I).

Expressed per $100 \mathrm{~g}$ of body weight, our values obtained in adult male Wistar rats weighing 400-500 g represent only $60 \%$ of those published by Koelz et al (1982) in the young female SpragueDawley rat. Although the weight of the animals was not noted by these authors, it can be estimated from their data that the HDL clearance rate per animal was similar to the one obtained in this paper. The fractional catabolic rate evaluated by 2 different methods (see legend to table I) is slightly but not significantly smaller in RICO than in SW rats and has a range of $0.078-0.10 h^{-1}$. Following the serum decay of 125) HDL (d 1.050-1.21) in young male Wistar rats fed a sucrose-purified high-carbohydrate diet, Van Tol et al (1978) found a FCR of $0.12 h^{-1}-F C R$ unmodified by removal of the liver.

Table I. HDL clearance rates (CR, expressed as $\mu / \cdot \mathrm{h}^{-1}$ per rat or per $100 \mathrm{~g}$ of rat) and fractional catabolic rates (FRC, \% $h^{-1}$ ) in normocholesterolemic (SW) and hypercholesterolemic (RICO) rats. Results are expressed as means \pm SEM $(N=5 ; S W ; N=4$; RICO) a FCR calculated as the ratio of constant hourly infusion rate to initial bolus; ${ }^{b}$ FCR calculated as the ratio of clearance rate ( $\mu$ l-h.per rat) to theoretical plasma volume ( $\mu \mathrm{l}$ per rat) of SW (3.9\% of . e body weight) and AICO rats $(4.1 \%$ of the body weight). ${ }^{\circ} 5$ data of $10 \% \cdot h^{-1}$.

\begin{tabular}{llcc}
\hline & Unit & SW rats & RICO rats \\
\hline $\mathrm{CR}$ & $\left(\mu \mid \cdot \mathrm{h}^{-1}\right.$ per rat $)$ & $1488 \pm 125$ & $1557 \pm 109$ \\
$\mathrm{CR}$ & $\left(\mu \cdot \mathrm{h}^{-1}\right.$ per $\left.100 \mathrm{~g} \mathrm{rat}\right)$ & $366 \pm 24$ & $320 \pm 22$ \\
& & $10.0^{\mathrm{c}}$ & \\
$\mathrm{FCR}^{\mathrm{a}}$ & $\left(\% \cdot \mathrm{h}^{-1}\right)$ & $9.2 \pm 0.5$ \\
$\mathrm{FCR}^{\mathrm{b}}$ & $\left(\% \cdot \mathrm{h}^{-1}\right)$ & $9.4 \pm 0.6$ & $7.8 \pm 0.5$ \\
\hline
\end{tabular}


The HDL clearance rate for a given tissue was expressed in terms of the plasma volume that would contain the same amount of radiolabelled compound (HDL clearance rate per $\mathbf{g}$ organ or for a tissue, $\mu l \cdot h-1 /$ organ $=$ protein-bound $\mathrm{dpm}$ into the tissue per $h$ /protein-bound $\mathrm{dpm}$ per $\mu \mathrm{l}$ plasma) (table II).

The most potent organs for degradation of HDL (HDL clearance rate for a tissue expressed per g) are the adrenals and spleen. Following these, the liver, kidney, small intestine or cæcum show a similar capacity to accumulate [ $\left.{ }^{14} \mathrm{C}\right]$ sucrose $\mathrm{HDL}$ $\left(11-27 \mu l h^{-1} / g\right)$.

Expressed per whole organ the liver, skeletal muscle, small intestine and kidney represent the main sites of HDL catabolism, but the spleen, testis or cæcum account for $5-15 \%$ of the HDL catabolic activity of the whole liver. Apart from the kidney, most of these results agree with those of Van Tol et al (1978), after iodinelabeled HDL or with Pittman and Steinberg (1986) using HDL labeled with 125 tyramine cellobiose-apoA-I. It is noteworthy that after 125 l labelling HDL or Apo A-I, the kidney was considered to have higher HDL catabolic activity than the liver, which does not agree with our observation after $\left[{ }^{14} \mathrm{C}\right]$ sucrose $\mathrm{HDL}$ in RICO or in normocholesterolemic animals.

Although the HDL clearance rate per $\mathrm{g}$ of skeletal muscle was very low (1.1-1.8

Table II. HDL Clearance rate for each tissue $\left(\mu \mid \cdot h^{-1}\right)$ per organ, per unit weight of tissue or expressed as a percentage of the liver HDL clearance rate (in brackets) in normocholesterolemic (SW) and hypercholesterolemic (RICO) rats. Results are expressed as means $\pm \operatorname{SEM}(N=5, S W ; N=4$, RICO). a : $P \leq 0.05$ RICO vs SW; ${ }^{b}$ : quadriceps femoris muscle; ${ }^{c}$ : calculated from an estimated muscular mass of $45 \%$ body weight (Donaldson, 1924).

\begin{tabular}{|c|c|c|c|c|c|c|c|}
\hline \multirow[b]{3}{*}{ Liver } & \multicolumn{4}{|c|}{ SW rats } & \multicolumn{3}{|c|}{ RICO rats } \\
\hline & \multicolumn{2}{|c|}{$\mu l \cdot h^{-1} / g \cdot o r g a n$} & \multicolumn{2}{|c|}{$\mu / \cdot h^{-1}$ per organ } & \multicolumn{2}{|c|}{$\mu / \cdot h^{-1} / g \cdot o r g a n$} & $\mu / \cdot r^{-1} /$ per organ \\
\hline & $\begin{array}{r}19.8 \\
\pm 1.7\end{array}$ & $(100)$ & $\begin{array}{r}297.1 \\
\pm 18.2\end{array}$ & $(100)$ & $\begin{array}{r}16.0 \\
\pm 1.9\end{array}$ & $(100)$ & $\begin{array}{r}273.0 \\
\pm 19.0\end{array}$ \\
\hline Skeletal muscle ${ }^{\mathrm{b}}$ & $\begin{array}{r}1.8 \\
\pm 0.2\end{array}$ & (9) & $\begin{array}{r}312.8^{\circ} \\
\pm 49.5\end{array}$ & $(105)$ & $\begin{array}{r}1.1 \\
\pm 0.1\end{array}$ & (7) & $\begin{array}{r}235.2 \quad(86) \\
\pm 27.7\end{array}$ \\
\hline Small intestine & $\begin{array}{r}14.2 \\
\pm 1.4\end{array}$ & (72) & $\begin{array}{r}93.3 \\
\pm 11.2\end{array}$ & (31) & $\begin{aligned} & 7.7^{a} \\
\pm & 0.4\end{aligned}$ & $(48)$ & $\begin{array}{r}68.3 \text { (25) } \\
\pm 1.4\end{array}$ \\
\hline Kidney & $\begin{array}{r}27.2 \\
\pm 1.7\end{array}$ & $(138)$ & $\begin{array}{r}72.9 \\
\pm 7.1\end{array}$ & $(28)$ & $\begin{array}{r}25.9 \\
\pm 2.4\end{array}$ & $(162)$ & $\begin{array}{r}64.9 \text { (24) } \\
\pm 6.1\end{array}$ \\
\hline Spleen & $\begin{array}{r}49.1 \\
\pm 5.2\end{array}$ & (248) & $\begin{array}{r}38.6 \\
\pm 8.4\end{array}$ & (13) & $\begin{array}{r}58.8 \\
\pm 6.0\end{array}$ & $(368)$ & $\begin{array}{r}38.6 \text { (14) } \\
\pm 2.7\end{array}$ \\
\hline Testis & $\begin{array}{r}5.9 \\
\pm 0.6\end{array}$ & $(30)$ & $\begin{array}{r}18.8 \\
\pm 1.5\end{array}$ & & $\begin{aligned} & 3.9^{\mathrm{a}} \\
\pm & 0.6\end{aligned}$ & (24) & $\begin{array}{l}12.8^{\mathrm{a}}(5) \\
\pm 1.6\end{array}$ \\
\hline Caecum & $\begin{array}{r}11.6 \\
\pm 2.9\end{array}$ & (59) & $\begin{array}{r}10.5 \\
\pm 3.3\end{array}$ & (4) & $\begin{array}{r}11.3 \\
\pm 3.3\end{array}$ & $(71)$ & $\begin{array}{r}11.6 \quad(4) \\
\pm 3.7\end{array}$ \\
\hline Colon & $\begin{array}{r}5.3 \\
\pm 1.3\end{array}$ & (26) & $\begin{array}{r}5.2 \\
\pm 1.5\end{array}$ & (2) & $\begin{array}{r}3.7 \\
\pm 0.6\end{array}$ & (23) & $\begin{array}{r}5.6 \text { (2) } \\
\pm 1.1\end{array}$ \\
\hline Adrenals & $\begin{array}{l}115.4 \\
\pm 4.3\end{array}$ & (583) & $\begin{array}{r}5.2 \\
\pm 0.5\end{array}$ & (2) & $\begin{array}{l}46.5^{a} \\
\pm 4.4\end{array}$ & $(291)$ & $\begin{aligned} & 1.9^{\mathrm{a}}(1) \\
\pm & 0.2\end{aligned}$ \\
\hline
\end{tabular}


$\left.\mu \mathrm{l} / \mathrm{h}^{-1}\right)$, skeletal muscle, which represents $45 \%$ of body weight (Donaldson, 1924), contributed very efficiently to the whole HDL clearance in SW as in RICO rats. It is noteworthy that the tissular HDL clearance rate, expressed per organ or per $g$ of tissue, although generally lower in RICO compared to SW rats, only appears significantly decreased in small intestine, testis and adrenals.

Let us underline, however that the sum of the HDL clearance rates for the tissues reported in table II takes into account only $46-57 \%$ of the measured HDL clearance rate for the plasma (about $1500 \mu \mathrm{l}$, table I). This is due to the fact that FCR determined from short experiments $(\leq 10$ h) only takes into account HDL exchanges between the plasma and extravascular compartment and not tissular uptake and degradation.

\section{REFERENCES}

Cardona-Sanclemente LE, Verneau C, Mathe D, Lutton C (1987) Cholesterol metabolism in the genetically hypercholesterolemic rat (RICO). I. Measurement of turnover processes. Biochim Biophys Acta 919, 205-212

Cardona-Sanclemente LE, Ferezou J, Lutton C (1988) Cholesterol metabolism in the geneti- cally hypercholesterolemic rat (RICO). II. Study of plasma lipoproteins and effect of dietary cholesterol. Biochim Biophys Acta 960, 382-389

Donaldson $\mathrm{HH}$ (1924) The Rat (Donaldson $\mathrm{HH}$, ed), PA

Koelz HR, Sherrill BC, Turley SD, Dietschy JM (1982) Correlation of low and high density lipoprotein binding in vivo with rates of lipoprotein degradation in the rat. A comparison of lipoproteins of rat and human origin. $J$ Biol Chem 257, 8061-8072

Pittman RC, Attie AD, Carew TE, Steinberg D (1979) Tissue sites of degradation of low density lipoprotein: application of a method for determining the fate of plasma proteins. Proc Natl Acad Sci USA 76, 5345-5349

Pittman RC, Carew TE, Glass CK, Green SR, Taylor CA, Attie AD (1983) A radioiodinated intracellularly trapped ligand for determining the sites of plasma protein degradation in vivo. Biochem J 212, 791-800

Pittman RC, Steinberg D (1986) A novel mechanism by which high density lipoprotein selectively delivers cholesterol esters to the liver. In: Receptor-Mediated Uptake in the Liver (Greten H, Windler E, Beisiegel U, eds), Springer-Verlag, Berlin, 109-119

Sérougne C, Ferezou J, Rukaj A (1984) Effects of excess dietary L-cystine on the rat plasma lipoproteins. Ann Nutr Metab 28, 311-320

Van Tol A, Van Gent T, Van't Hooft FM, Vlaspoder $F$ (1978) High density lipoprotein catabolism before and after partial hepatectomy. Atherosclerosis 29, 439-448 